\title{
Seismic vulnerability analysis of a two-story family dwelling in confined masonry in Cuenca, Ecuador
}

\section{H. García ${ }^{1}$, G. Degrande ${ }^{2}$}

${ }^{1} \mathrm{PhD}$ student of the Department of Civil Engineering, KU Leuven, Leuven, Belgium.

2 Professor, Department of Civil Engineering, KU Leuven, Leuven, Belgium.

Autores para correspondencia: hernan.garcia@kuleuven.be, geert.degrande@kuleuven.be

Fecha de recepción: 28 de abril 2017 - Fecha de aceptación: 4 de noviembre 2017

\section{RESUMEN}

Este artículo presenta la evaluación de vulnerabilidad sísmica de una vivienda unifamiliar de mampostería confinada, común en la ciudad de Cuenca, Ecuador. Las propiedades macroscópicas de las mamposterías, de ladrillo hueco y macizo, se obtuvieron mediante análisis por elementos finitos de modelos mesoscópicos de pilares de mampostería. La edificación se modeló utilizando un método de pórtico equivalente, en el cual las paredes se modelan como macro-elementos. En el modelo, las columnas y vigas reforzadas se analizan como elementos lineales y losas de entrepiso como elementos bidimensionales ortotrópicos. Se construyen varios modelos del edificio, variando las propiedades de los materiales pero no la geometría de la vivienda. El análisis inicia con un cálculo no lineal utilizando un método pushover en todos los modelos, este estudio permite definir los estados límites de la edificación y construir modelos simplificados equivalentes a partir de un macro-elemento, que incorpora modos de falla por corte y flexión, y que además es capaz de reproducir el comportamiento cíclico similar al de un modelo tridimensional. Esto permite realizar análisis dinámicos no lineales en el macroelemento equivalente, utilizando diferentes registros sísmicos seleccionados de la base de datos PEER Ground Motion Database y compatibles con el espectro de diseño ecuatoriano para varios niveles de aceleración del suelo. La respuesta máxima de cada análisis dinámico es comparada con diferentes niveles de estado límite de la estructura. Las curvas de fragilidad se determinaron usando el método de máxima probabilidad (maximum likelihood). La metodología propuesta puede utilizarse para el análisis de vulnerabilidad sísmica en casos donde se dispone de pocos datos. Debido a los altos niveles de incertidumbre, se recomienda realizar análisis y experimentos adicionales sobre los materiales y los componentes estructurales.

Palabras clave: Evaluación de vulnerabilidad sísmica, vivienda unifamiliar, mampostería confinada, análisis pushover, macro-elemento equivalente, curvas de fragilidad, Cuenca, Ecuador.

\begin{abstract}
This paper presents a seismic vulnerability assessment of a single-family dwelling in confined masonry, a common construction type in the city of Cuenca, Ecuador. The macroscopic properties of hollow and solid brick masonry are derived from mesoscopic finite element analyses of masonry piers. The structure is modeled using an equivalent frame method, in which masonry walls are defined as piers or spandrels using a macro-element model; reinforced columns and beams and orthotropic floor slabs are also included. Several models, considering a deterministic geometry and stochastic properties of masonry, are analyzed using a quasi-static pushover method. The results of these analyses are used to define a single equivalent macro-element that incorporates in-plane shear and flexural failure modes and is capable of reproducing the cyclic behavior of the 3D model. Non-linear dynamic time history analyses are finally performed on the single equivalent macro-element for different earthquake ground motions that are selected from the PEER Ground Motion Database and that are compatible with the Ecuadorian design spectrum for several PGA levels. The maximum response is compared with different performance levels and the fragility curves are determined using a maximum likelihood analysis. The proposed methodology can be used for seismic vulnerability analysis when few data are available, but
\end{abstract}


is subject to high levels of uncertainty, so further analysis and experiments on materials and structural components are needed.

Keywords: Seismic vulnerability analysis, single family dwelling, confined masonry, pushover analysis, equivalent frame method, fragility curves, Cuenca, Ecuador.

\section{INTRODUCTION}

Ecuador lies on the eastern rim of the seismically active Pacific Ring of Fire. Relative motion between the Nazca plate and the South-American plate is the main source of tectonic earthquakes. At least 38 earthquakes of magnitude $M_{w} 7.0$ or higher were reported since 1541, resulting in an estimated number of 80,000 casualties. The most recent is the $M_{w} 7.8$ Pedernales earthquake of 16 April 2016.

Cuenca is the third largest city of Ecuador with a population of about half a million. The city center contains a lot of European style buildings with traditional materials as timber and adobe and is listed as a UNESCO World Heritage Trust site since 1999. In the suburbs, construction practice changed since the 1980s, and timber and adobe were replaced by reinforced concrete frames with infill masonry, consisting of bricks or blocks. $80 \%$ of Cuenca's building stock consists of low rise masonry buildings (Jiménez, 2002).

Cuenca is located in a zone with medium seismic hazard (PGA ${ }^{1}$ on bedrock of 0.25 g) (Comité Ejecutivo de la Norma Ecuatoriana de la Construcción, 2011); it has experienced a number of historical earthquakes with magnitudes ranging from $M_{w} 4.0$ to $M_{w}$ 4.9. The absence of recent destructive earthquakes and the lack of historical data on important seismic events and earthquake induced structural damage, resulted in a construction practice without much consideration of earthquake resistant design. Most masonry buildings were constructed without quality control, not fulfilling seismic building codes, resulting in a high level of uncertainty on building performance. Therefore, a large-scale vulnerability analysis of unreinforced masonry and reinforced concrete buildings was conducted in 1999 by the research group Red Sísmica del Austro of the University of Cuenca (Bermeo \& Loaiza, 2001; Jiménez, 2002), using a methodology based on the Italian vulnerability index method (Benedetti, Benzoni \& Parisi, 1988). This study predicted high seismic vulnerability, especially of unreinforced masonry structures (Fig. 1).

The present paper complements the previous study in presenting a seismic vulnerability study of a two-story single-family dwelling, constructed with confined masonry; this is a very common construction method in Cuenca.

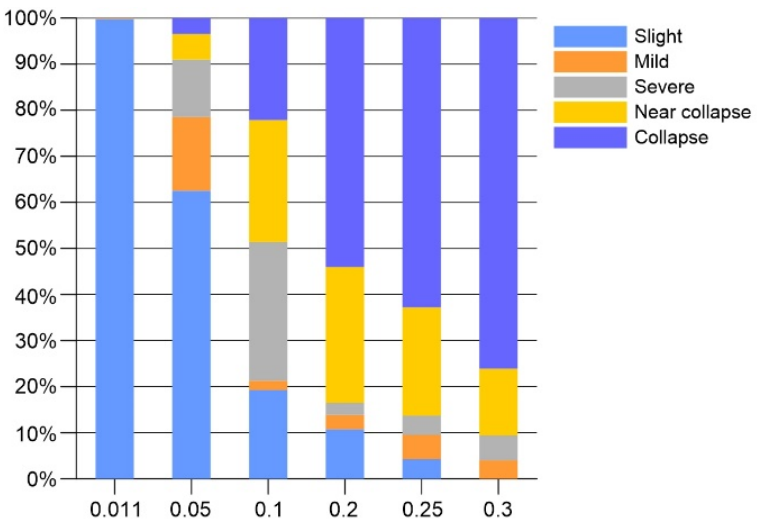

(a)

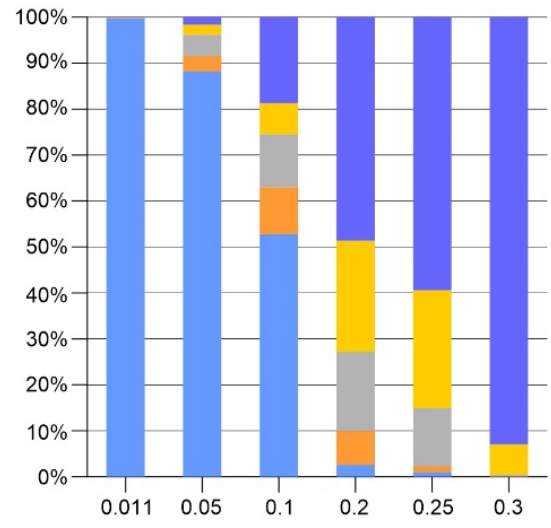

(b)

Figure 1. Seismic vulnerability of (a) unreinforced masonry and (b) reinforced concrete buildings in Cuenca (Bermeo \& Loaiza, 2001). Performance level as a function of PGA.

\footnotetext{
1 PGA = Peak Ground Acceleration
} 
The influence of masonry strength, depending on the type of infill (hollow or solid bricks) on the structural performance is investigated, using an equivalent frame method (Lagomarsino, Penna, Galasco \& Cattari, 2013) in which masonry is modeled with a macro-element model (Penna, Lagomarsino \& Galasco, 2014). The results of this study can be used to raise awareness among local authorities to implement more rigorous control during planning, design and construction.

Section 2 presents the geometrical and material characteristics of the two-story confined masonry building. In section 3, the seismic capacity of the structure is determined by means of a quasi-static pushover analyses, using the equivalent frame method (Lagomarsino et al., 2013). These results are subsequently used to define a single equivalent macro-element that is able to approximate the cyclic response of the 3D model. Section 4 presents the vulnerability analysis, based on the results of nonlinear dynamic time history analyses on single equivalent macro-elements, subjected to transient seismic ground motions that are compatible with the response spectrum of the Ecuadorian seismic code for different PGA levels. The maximum response obtained is compared with different performance levels and the fragility curves are determined using a maximum likelihood analysis.

\section{CASE STUDY}

Figure 2 presents plan views, as well as a frontal and back view of a two-story single family dwelling in confined masonry. The building is part of the residential area Laguna del Sol, consisting of 325 houses and located approximately $6 \mathrm{~km}$ east of the city center of Cuenca (Quito, 2012). This structure is representative for recent housing projects in Cuenca. It has a living room, kitchen and garage on the ground floor, bedrooms on the first story, and a double pitched roof. Each house is $6 \mathrm{~m}$ wide, $9 \mathrm{~m}$ long and $6.4 \mathrm{~m}$ high. The building is composed of unreinforced masonry walls, confined between reinforced concrete columns and beams, and reinforced concrete orthotropic floor slabs.
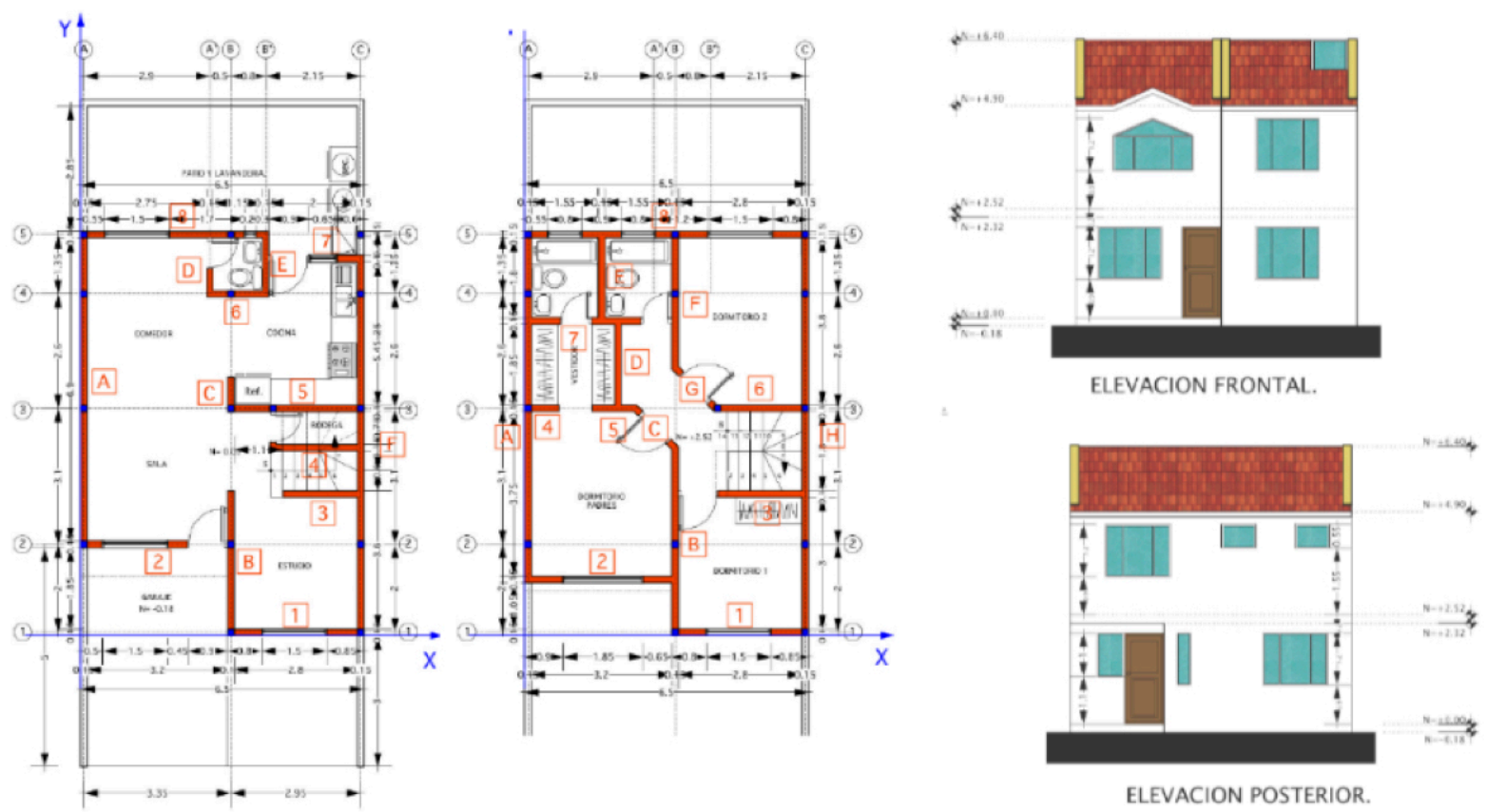

Figure 2. Plan views, frontal view and back view of a two-story single-family dwelling in the residential area Laguna del Sol in Cuenca (Quito, 2012).

All masonry walls consist of hollow or solid bricks and have a thickness of $0.15 \mathrm{~m}$. The material characteristics of hollow and solid bricks, as well as mortar layers, have been determined by means of laboratory testing at the University of Cuenca (Neira \& Ojeda, 2008). Table 1 summarizes the 
dimensions and the average compressive $f_{\mathrm{cb}}$ and tensile strength $f_{\mathrm{tb}}$ as well as the average Young's modulus $E_{\mathrm{b}}$ and shear modulus $G_{\mathrm{b}}$, as determined by means of 22 compression tests on hollow bricks and 33 compression tests on solid bricks. Table 1 also summarizes the characteristics of bricks and mortar layer, determined from 18 compression tests on cubes with a side of $0.05 \mathrm{~m}$. The Young's modulus from experimental tests define a lognormal distribution used to generate stochastic material properties of hollow and solid bricks, and mortar.

Table 1. Dimensions and average mechanical properties of hollow and solid bricks and mortar (Neira \& Ojeda, 1992).

\begin{tabular}{lccccccc}
\hline & $\begin{array}{c}l_{\mathrm{b}} \\
{[\mathrm{m}]}\end{array}$ & $\begin{array}{c}w_{\mathrm{b}} \\
{[\mathrm{m}]}\end{array}$ & $\begin{array}{c}h_{\mathrm{b}} \\
{[\mathrm{m}]}\end{array}$ & $\begin{array}{c}f_{\mathrm{cb}} \\
{[\mathrm{MPa}]}\end{array}$ & $\begin{array}{c}f_{\mathrm{tb}} \\
{[\mathrm{MPa}]}\end{array}$ & $\begin{array}{c}E_{\mathrm{b}} \\
{[\mathrm{MPa}]}\end{array}$ & $\begin{array}{c}G_{\mathrm{b}} \\
{[\mathrm{MPa}]}\end{array}$ \\
\hline Hollow & 0.30 & 0.13 & 0.20 & 2.77 & 0.098 & 709 & 284 \\
Solid & 0.28 & 0.14 & 0.09 & 8.3 & 0.3 & 3063 & 1225 \\
\hline & $l_{\mathrm{m}}$ & $w_{\mathrm{m}}$ & $h_{\mathrm{m}}$ & $f_{\mathrm{cm}}$ & $f_{\mathrm{tm}}$ & $E_{\mathrm{m}}$ & $G_{\mathrm{m}}$ \\
& {$[\mathrm{m}]$} & {$[\mathrm{m}]$} & {$[\mathrm{m}]$} & {$[\mathrm{MPa}]$} & {$[\mathrm{MPa}]$} & {$[\mathrm{MPa}]$} & {$[\mathrm{MPa}]$} \\
\hline Mortar & 0.05 & 0.05 & 0.05 & 7.54 & 0.75 & 1508 & 603 \\
\hline
\end{tabular}

The reinforced concrete columns and beams have a rectangular section of 0.15 by $0.20 \mathrm{~m}$, where the former dimension is along the thickness of the walls. The Young's modulus of concrete is estimated as $E_{c}=4700 \sqrt{f_{c}}$ for a compressive strength $f_{\mathrm{c}}=18 \mathrm{MPa}$ (Neira \& Ojeda, 1992) and Poisson's ratio as $v=0.25$. The columns have a prefabricated steel cage reinforcement with 4 longitudinal bars with diameter $9.0 \mathrm{~mm}$ and stirrups with diameter $5.5 \mathrm{~mm}$ every $0.150 \mathrm{~m}$; the steel has a yield strength $f_{\mathrm{y}}=$ $500 \mathrm{MPa}$.

Floors slabs are made of reinforced concrete T-sections with a width of $0.7 \mathrm{~m}$ and a height of 0.21 $\mathrm{m}$; the flange thickness is $0.06 \mathrm{~m}$ and the width of the web is $0.10 \mathrm{~m}$. The top reinforcement is a wire mesh with diameter of $4.5 \mathrm{~mm}$ and spacing $0.15 \mathrm{~m}$; a rebar with diameter of $12 \mathrm{~mm}$ is placed at the bottom. The compressive strength of the concrete is equal to $f_{\mathrm{c}}=21 \mathrm{MPa}$; the steel has a yield strength $f_{\mathrm{y}}=420 \mathrm{MPa}$. The floors are orthotropic and carry loads mainly in the $x$-direction (Fig. 2).

The foundation consists of shallow concrete strip footings on very dense soil or soft rock that is catalogued as soil type C2 with a shear wave velocity between 360 and $760 \mathrm{~m} \mathrm{~s}^{-1}$ in the Ecuadorian seismic code (Comité Ejecutivo de la Norma Ecuatoriana de la Construcción, 2011).

\section{PUSHOVER ANALYSIS}

\subsection{Equivalent frame model}

The capacity of the single-family dwelling to carry lateral earthquake loads is determined by means of a displacement controlled pushover analysis (non-linear static analysis). To this purpose, a 3D equivalent frame model of the structure is built using the TREMURI ${ }^{2}$ software, as proposed by Lagomarsino, Galasco, Penna \& Cattari (2008) and Lagomarsino et al. (2013).

The walls are defined by means of the coordinates of a corner point $(x, y)$ and the angle $\theta_{z}$ formed by their vertical plane with the $x$-axis. Fig. 3 shows the ground floor and first floor plans, as well as the wall numbering implemented in TREMURI ( 7 walls parallel to the $x$ - axis and 4 walls parallel to the $y$ axis).

The building is divided in frames, which, depending on the configuration of openings, are composed of piers or spandrels and rigid nodes. The identification and geometry of each component follows conventional criteria (Lagomarsino et al., 2013), which are supported by damage surveys after earthquakes and experimental campaigns. Piers are defined as elements carrying vertical and horizontal

\footnotetext{
2 TREMURI is a computer program specifically developed for the structural and seismic analysis of masonry buildings
} 
loads. Spandrels couple the response and modify the boundary of adjacent piers. Fig. 4 shows an example of three walls (P1, P7 and P9), composed of masonry panels, reinforced concrete elements (columns and beams) and openings, modeled in TREMURI.

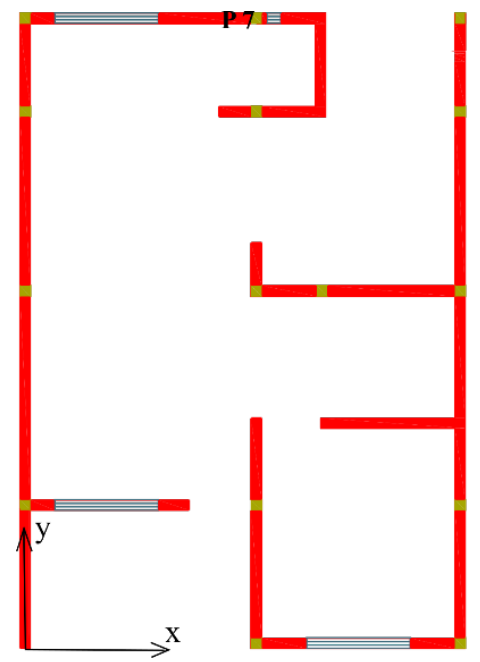

(a)

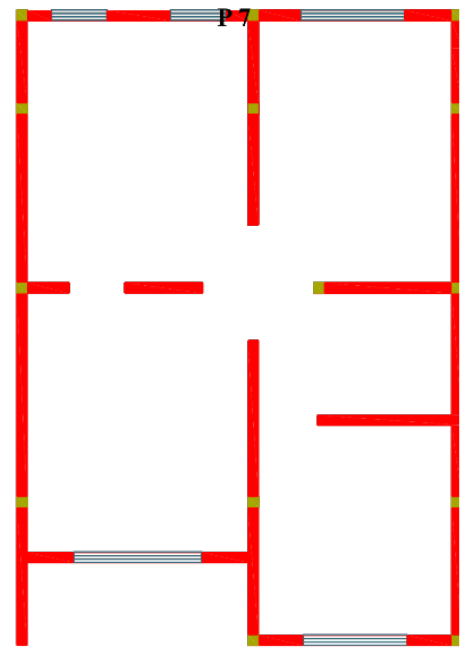

(b)

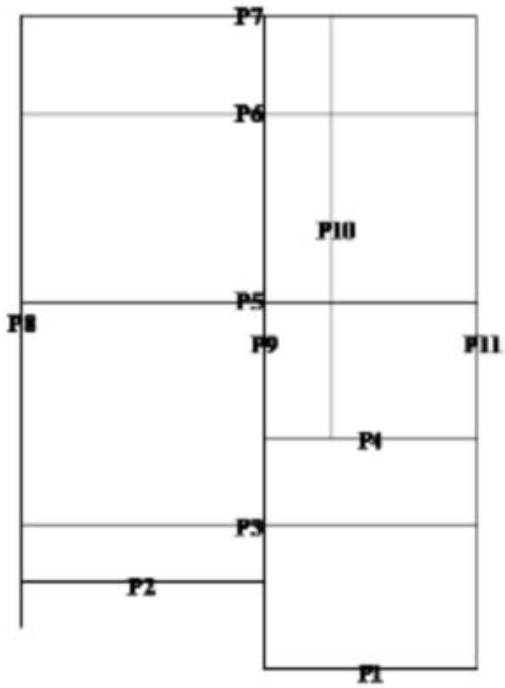

(c)

Figure 3. (a \& b) Plan of the ground floor and (c) wall numbering in the TREMURI model of the structure.
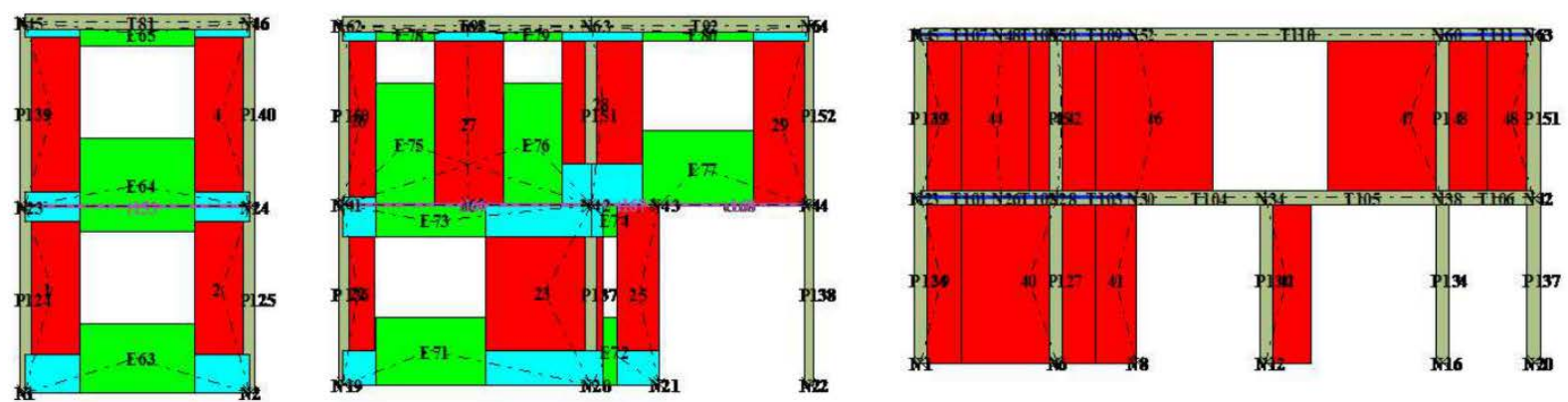

Figure 4. Walls P1, P7 and P9 modelled with TREMURI. Piers are indicated in red, spandrels in dark green, rigid nodes in blue, and columns and beams in light green.

Piers and spandrels are modeled using a one-dimensional macro-element that can represent flexural-rocking and shear behavior (Penna et al., 2014). The macro-element model is ideally subdivided into three parts, two zero thickness interface elements with axial, compression and rotation degrees of freedom and one central part considered rigid (only shear deformation) with axial and rotation degrees of freedom. Relative displacement and rotation is allowed between the interface elements and the extremities of the central body. The initial elastic phase is determined by the element's axial, flexural and shear stiffness according to their geometric and mechanical properties. Non-linear terms are added to the stiffness of the macro-element to account for cracking, toe-crushing and shear damage in the inelastic phase. The behavior of masonry piers and spandrels is considered not to be affected by the interaction with the columns; an increase of ductility is expected (Tomazevic, 1999), however. A complete explanation for the input of walls and macro-elements is given in (Lagomarsino et al., 2008).

Concrete beams and columns are modeled as 2D and 3D elements, respectively. Their inelastic behavior is idealized by assuming elastic-perfectly plastic hinges concentrated at the ends of the element. In the elastic phase, the stiffness is determined by shear and flexural contribution; the contribution of the reinforcement to the stiffness is neglected. Shear and compressive/tensile failures are assumed as brittle, while the behavior due to combined axial force and bending moment is assumed to be ductile. 
The shear strength is computed according to the criteria proposed in NTC $2008^{3}$ and EC $8^{4}$ for low to medium ductility classes (European Committee for Standardization, 2004). The formation of plastic hinges under the combined action of axial force and bending moment is determined by comparing the elastic prediction with limit values of the $\mathrm{M}-\mathrm{N}$ interaction diagram, which is computed considering plane sections and perfect bond between concrete and steel bars.

Floors are modeled using elastic orthotropic membrane finite elements ( 3 or 4 nodes) with two degrees of freedom $\left(u_{\mathrm{x}}, u_{\mathrm{y}}\right)$ at each node in the global coordinate system. The elastic constants are the Young's modulus $E_{1}$ in the load carrying direction, the Young's modulus $E_{2}$ in the orthogonal direction, Poisson's ratio $v_{12}$, and the shear modulus $G_{12}$. The Young's moduli $E_{1}$ and $E_{2}$ represent the stiffness of the membrane along two perpendicular directions, affecting the degree of connection between walls and horizontal diaphragm and providing a kinematic relation for nodes belonging to a wall-floor intersection. The shear modulus $G_{12}$ influences the tangential stiffness of the diaphragm, therefore the horizontal force transferred among walls.

\subsection{Mechanical characteristics of masonry panels}

The macroscopic properties of a homogenized masonry panel are derived from mesoscopic finite element analyses of masonry panels consisting of bricks and mortar layers that are loaded in compression and shear, respectively. The first analysis considers a masonry panel loaded in compression. Figure 5a shows a 3D mesoscopic finite element model of a masonry panel consisting of five rows of two and a half bricks and mortar layers, bounded by two rigid steel beams. Eight-node hexahedron solid elements with a size corresponding to half a brick are used. The panel is fixed at the bottom, while the nodes at the top are constrained to move in the vertical direction. The masonry panel is loaded by a uniformly distributed uni-axial compressive load at the top.

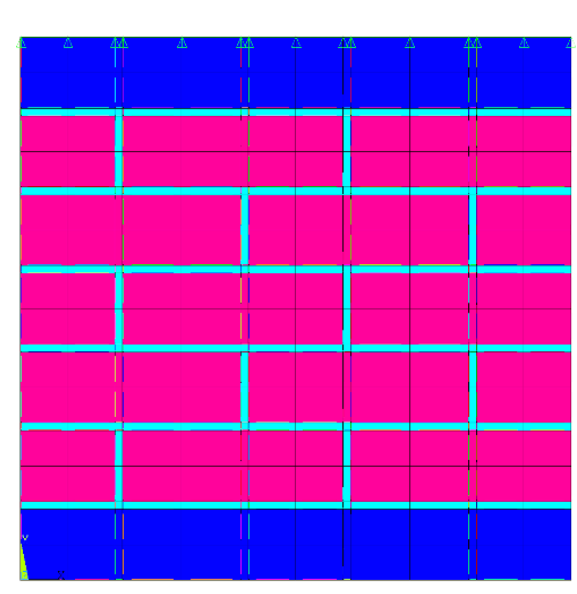

(a)

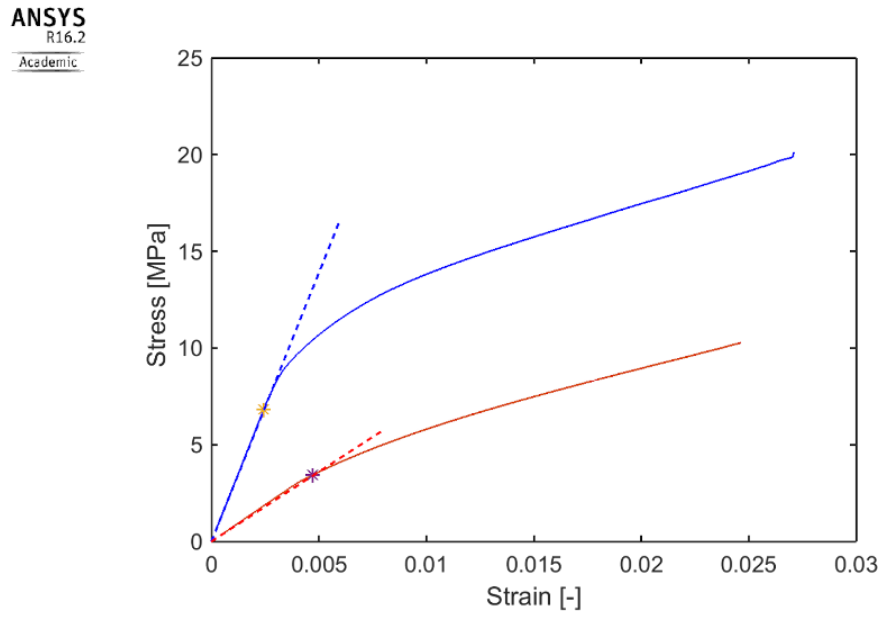

(b)

Figure 5. (a) Mesoscopic finite element model of a masonry panel consisting of five rows of two and a half solid bricks (red) and mortar layers (light blue), bounded by two rigid steel beams (dark blue), and (b) stress-strain curve of a masonry panel consisting of hollow (red line) and solid (blue line) bricks under uniaxial compressive loading.

The cohesion and internal angle of friction of the bricks and mortar layer were determined from their compressive and tensile strength. The non-linear behavior of these constituents is accounted for by

\footnotetext{
3 NTC 2008 (2008): Italian Seismic Code - Nuove Norme Tecniche per le Costruzioni, G.U. n. 29, 4 Febbraio 2008, S.O. n. 30. D.M. del Ministero delle Infrastrutture e dei Trasporti 14 Gennaio 2008 (in Italian).

4 Eurocode 8: Design of structures for earthquake resistance (abbreviated EN 1998 or, informally, EC 8) describes how to design structures in seismic zone, using the limit state design philosophy.
} 
means of a Drucker-Prager failure criterion that fits the Mohr-Coulomb criterion along the compression meridian.

Figure $5 \mathrm{~b}$ shows the stress-strain curve of a masonry panel consisting of hollow and solid bricks, respectively, under compressive loading. Initially, the response is linear elastic (the tangent to the stressstrain curves is indicated in dashed lines on Fig. 5b) and the Young's modulus of the homogenized macroscopic masonry can be computed as:

$$
E=\frac{E_{\mathrm{b}} E_{\mathrm{m}}\left(h_{\mathrm{b}}+h_{\mathrm{m}}\right)}{h_{\mathrm{b}} E_{\mathrm{m}}+h_{\mathrm{m}} E_{\mathrm{b}}}
$$

where the thickness and the Young's modulus of the brick and mortar have been specified in Table 1 . The mean Young's modulus of the hollow and solid brick masonry is equal to $724 \mathrm{MPa}$ and $2770 \mathrm{MPa}$, respectively. From the stress-strain curves in Fig. 5b, the mean compressive strength $f_{\mathrm{m}}$, estimated the on-set of non-linear deformation, of the hollow and solid brick masonry is $3.44 \mathrm{MPa}$ and $6.84 \mathrm{MPa}$, respectively.

The second analysis considers a masonry panel loaded in shear. Figure 6a shows a 3D mesoscopic finite element model of a masonry panel consisting of three rows of one brick and mortar layers, bounded by two horizontal and three lateral rigid steel plates. Eight-node hexahedron solid elements with a size corresponding to half a brick are used. The bottom panel and the two left plates are fixed, while the nodes at the top are constrained to move in the vertical direction and the nodes in contact with the right plate are constrained to move in the horizontal direction. The masonry panel is loaded by a uniformly distributed uni-axial compressive load at the top and by lateral uniformly distributed load at the right steel plate.

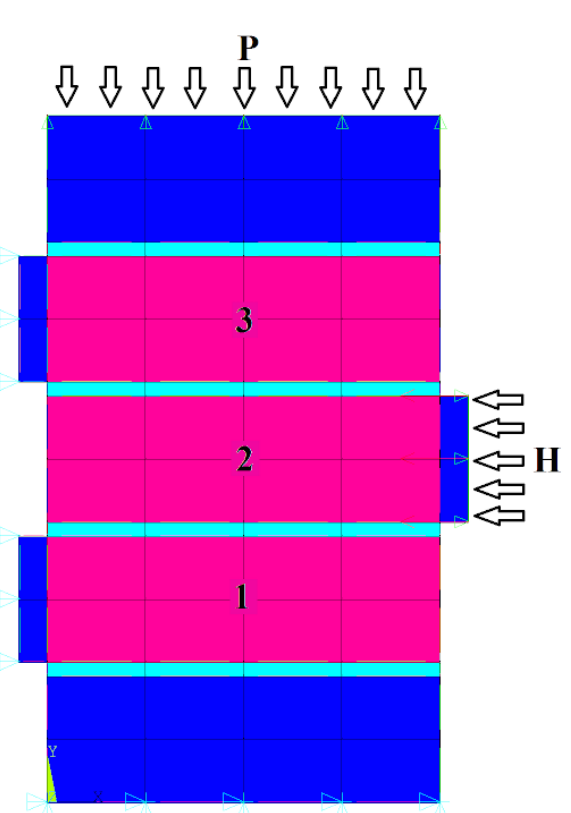

(a)
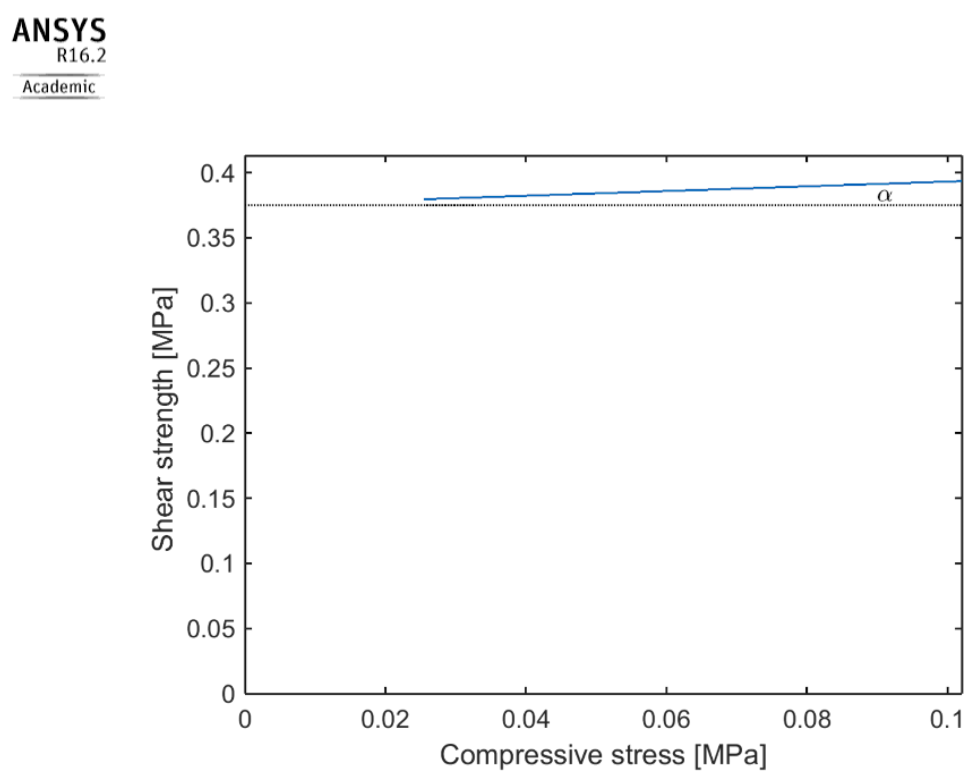

(b)

Figure 6. (a) Mesoscopic finite element model of a masonry panel consisting of three rows of one brick and mortar layers, bounded by two horizontal and three lateral rigid steel, and (b) shear strength for different compression loads for the masonry panel consisting of solid bricks.

Figure 6b shows the shear strength $f_{\mathrm{v}}=H /(2 A)$, whit $H$ the maximum shear force and $A$ the crosssectional area, for different compressive loads of the masonry panel consisting of solid bricks. The friction coefficient $\mu$ is defined as $\mu=\tan \alpha$, where $\alpha$ is represented in Fig. 6b. In total 100 analyses. 
Table 2. Average macroscopic properties for the homogenized masonry panels composed of hollow and solid bricks.

\begin{tabular}{lcccccccc}
\hline & $\begin{array}{c}\text { Young's } \\
\text { modulus }\end{array}$ & $\begin{array}{c}\text { Shear } \\
\text { modulus }\end{array}$ & Density & $\begin{array}{c}\text { Compressive } \\
\text { strength }\end{array}$ & Cohesion & $\begin{array}{c}\text { Friction } \\
\text { coefficient }\end{array}$ & $\begin{array}{c}\text { Shear } \\
\text { parameter }\end{array}$ & $\begin{array}{c}\text { Softening } \\
\text { parameter }\end{array}$ \\
\hline $\begin{array}{l}E \\
{[\mathrm{MPa}]}\end{array}$ & $\begin{array}{c}G \\
{[\mathrm{MPa}]}\end{array}$ & {$\left[\mathrm{kg} / \mathrm{m}^{3}\right]$} & $\begin{array}{c}f_{\mathrm{tm}} \\
{[\mathrm{MPa}]}\end{array}$ & $\begin{array}{c}f_{\mathrm{vo}} \\
{[\mathrm{MPa}]}\end{array}$ & $\begin{array}{c}\mu \\
{[-]}\end{array}$ & $\begin{array}{c}G c_{\mathrm{t}} \\
{[-]}\end{array}$ & $\begin{array}{c}\beta \\
{[-]}\end{array}$ \\
\hline Hollow & 724 & 291 & 1600 & 3.44 & 0.091 & 0.13 & 1 & 0.1 \\
\hline Solid & 2770 & 1111 & 1800 & 6.84 & 0.3 & 0.145 & 2 & 0.4 \\
\hline
\end{tabular}

Table 2 summarizes the result of 100 finite element analyses, using randomly selected properties of bricks and mortar, to define the mean of all macroscopic properties of the homogenized masonry panels, which are composed of hollow and solid bricks respectively. In addition, a dimensionless shear parameter $G c_{\mathrm{t}}$ is defined as the product of the shear modulus $G$ and a non-linear shear deformability parameter $c_{\mathrm{t}}$, that characterizes the tangent stiffness of masonry panels (Lagomarsino et al., 2013); it is normally obtained based on experimental results (Penna et al., 2014). A softening parameter $\beta$ is used to define the slope of the softening branch of a toughness function that describes the maximum available energy dissipation consistent with a specific damage level (Lagomarsino et al., 2013).

\subsection{Natural vibration periods and modes}

The motion in the $x$-direction is the dominant behavior of the structure with hollow and solid bricks. The mean first eigenperiod of the structure with hollow bricks is $0.313 \mathrm{~s}$. The structure with solid bricks is stiffer and has mean first eigenperiod of $0.188 \mathrm{~s}$. The mean mass participation factor of the first eigenmode is 0.82 and 0.83 for the structure built with hollow and solid bricks, respectively.

\subsection{Pushover analysis}

A displacement controlled pushover analysis (non-linear static analysis) is performed using an incremental force with a spatial distribution corresponding to the first eigenmode of the structure.

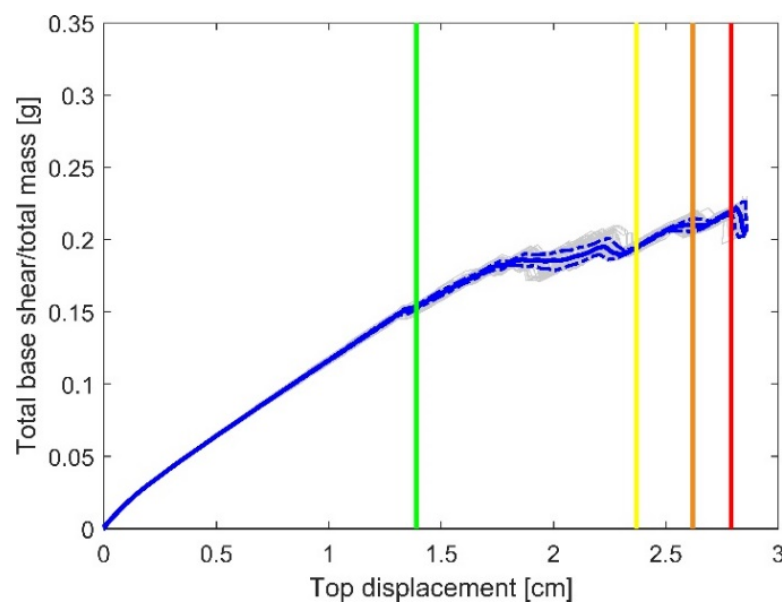

(a)

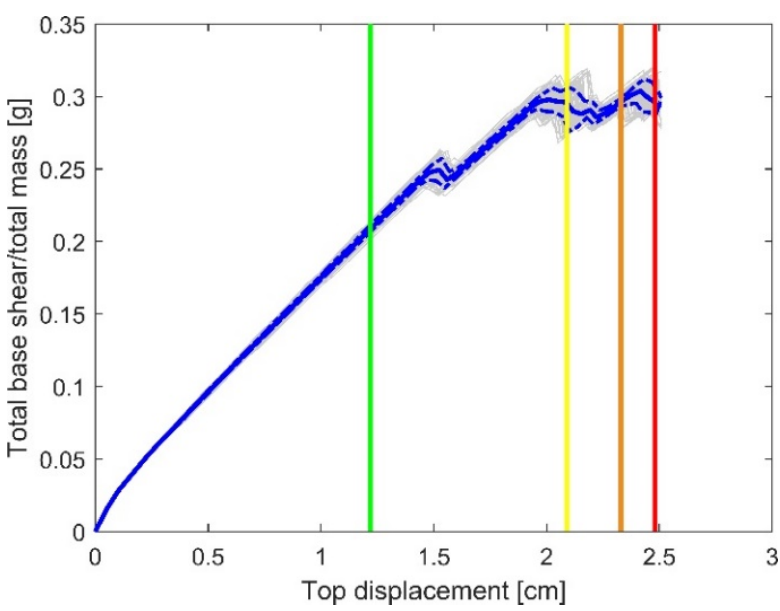

(b)

Figure 7. Pushover curve (blue line) for structures with (a) hollow and (b) solid bricks. Limit performance levels based on roof displacement are superimposed: fully operational (green line), operational (yellow line), life safe (orange line) and near collapse (red line).

Figure 7 shows the pushover curves for buildings composed of hollow and solid bricks; the total base shear force divided by the total mass of the building (equal to $82486 \mathrm{~kg}$ for the structure with hollow bricks and $84118 \mathrm{~kg}$ for the structure with solid bricks) is plotted as a function of the roof lateral 
displacement in the $x$-direction. In the initial elastic phase, the load is mostly carried by the walls. The operational performance level is characterized by a sudden loss of stiffness; an increase of force produces stresses that exceed the capacity of different masonry panels, starting with wall P7. This is followed by stiffness reduction as forces are redistributed through remaining bearing walls and reinforced concrete columns, resulting into a more ductile behavior, however with continuing presence of non-ductile failure from remaining masonry walls. After further load increment, the building finally collapses. Comparing the pushover curves of the structure with hollow and solid bricks, it can be noticed that an increase of overall stiffness can be attributed to improved masonry characteristics, while a decrease of ductility is a consequence of high stresses exceeding the strength of remaining walls and concrete columns.

Figure 8 shows the stress condition of masonry panels and columns in wall P7 of model 54 (randomly selected) with hollow bricks in the last step of the pushover analysis. On the ground floor, two masonry piers with insufficient strength fail due to shear, two piers and a spandrel are in the shear plastic phase next to collapse, one spandrel is in the inelastic phase and two reinforced columns fail due to bending. On the first story, the masonry piers around the two small openings have higher shear resistance and are subjected to lower stress levels in the inelastic phase; therefore, higher stresses occur in adjacent walls, so the remainder of the masonry piers and spandrels are in the shear plastic phase.

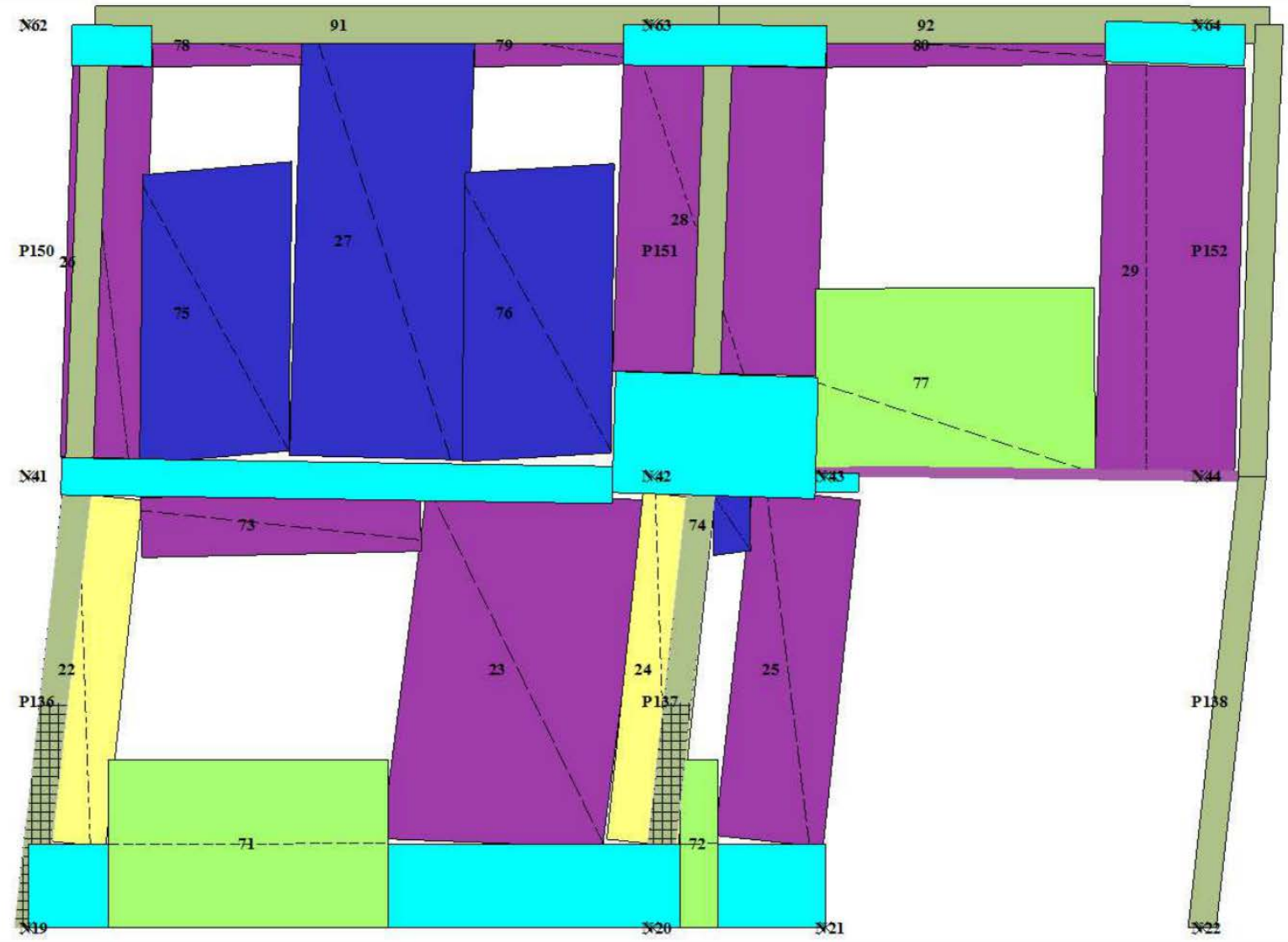

Figure 8. Final stress condition in wall P7 of the structure with hollow bricks in the last step of the pushover analysis, indicating rigid nodes (cyan) and elements in the inelastic phase (blue), the shear plastic phase (purple), and shear collapse (yellow), and columns failing due to bending (crossed lines).

\subsection{Equivalent macro-element}

In practice, simplified analysis based on displacement-based methods is used for seismic assessment (Freeman, 1998; Fajfar, 2000). In this paper, the roof displacements of the 3D models are estimated 
using a single equivalent macro-element, which are calibrated from equivalent SDOF systems ${ }^{5}$. The advantages of the single macro-element are twofold: the hysteretic behaviors are calibrated from the 3D model and the simplified systems are capable of modeling shear or flexural failure modes. Moreover, other methods can give inaccurate results for structures with first eigenperiod lower than $0.5 \mathrm{~s}$, which is in general the case for low-rise confined masonry buildings. FEMA $440^{6}$, presents results where the response of an equivalent SDOF system with a period below $0.5 \mathrm{~s}$, can either be overestimated (capacity spectrum method of ATC- $40^{7}$ ) or underestimated (coefficient method of FEMA 356 ${ }^{8}$ ). Other methods are based on simplified representations of the hysteretic constitutive behavior of masonry structures.

The equivalent SDOF system is deduced from the first mode pushover curve, relating the base shear force $V_{\mathrm{b} 1}$ to the roof displacement $u_{\mathrm{r} 1}$, resulting in a relation between the resisting force $F_{\mathrm{s} 1}=V_{\mathrm{b} 1} / \Gamma_{1}$ and the dimensionless displacement $D_{1}=u_{\mathrm{r} 1} /\left(\Gamma_{1} \phi_{\mathrm{r} 1}\right)$, where $\Gamma_{1}$ is the first mode participation factor and $\phi_{\mathrm{r} 1}$ is the lateral roof displacement in the first mode (Chopra \& Goel, 2002). The mean participation factor $\phi_{\mathrm{r} 1}$ of the structure with hollow and solid bricks is equal to 1.38 and 1.30, respectively. Fig. 9 shows the transformation of the pushover curve to an equivalent SDOF system and its elastic-perfectly plastic approximation, with the yield values $D_{1 y}$ and $F_{\text {s1y }}$.

The equivalent single macro-element must have the same period $T^{\star}$ and mass $m^{\star}$ as the equivalent SDOF system. Therefore, the mechanical and geometrical properties of this element should result in a lateral stiffness $k^{\star}=4 \pi^{2} / T^{\star 2}$. If it is assumed that the single macro-element is fixed at the bottom node $i$ and cannot rotate at the top node $j$, and if it is taken into consideration that, in this particular case, the bending and shear deformations decouple from the axial deformation, the 8 by 8 stiffness matrix of the macro-element (Penna et al., 2014) reduces to the following 2 by 2 stiffness matrix, relating the lateral load $V_{j}$ at the top node $j$ and the bending moment $M_{e}$ at the central node $e$, to the corresponding lateral displacement $u_{j}$ and rotation $\varphi_{e}$ :

$$
\left[\begin{array}{cc}
\frac{G b t}{h} & G b t \\
G b t & G b t+\frac{E t b^{3}}{3 h}
\end{array}\right]\left\{\begin{array}{l}
u_{j} \\
\varphi_{e}
\end{array}\right\}=\left\{\begin{array}{l}
V_{j} \\
M_{e}
\end{array}\right\}
$$

where $h$ is the height, $b$ the width, and $t$ the thickness, $G$ the shear modulus and $E$ the Young's modulus of the macro-element. The lateral stiffness $k^{\star}$ of the macro-element equals the lateral force $V_{j}$ needed to impose a unit lateral displacement $u_{j}$, while the moment $M_{e}$ equals zero:

$$
k^{\star}=\frac{b^{3} t E}{3 h^{3}+2 h b^{2}(1+v)}
$$

where $v$ is the Poisson's ratio of the masonry. Given $k^{\star}, E$ and $v$ and choosing values for $h$ and $t$, allows computing the width $b$ of the equivalent single macro-element that has the same lateral stiffness as the structure under consideration.

The pushover curve of the MDOF system is used to define a failure mode that characterizes the failure of the single macro-element model. If the failure is dominated by an axial-flexural behavior, the macro-element should reach the maximum moment before failing in shear. If the failure is due to shear, the wall should reach the maximum shear force before failing in the axial-flexural mode. In this way, it is possible to define the compressive strength, friction coefficient and cohesion of the single macro-

\footnotetext{
5 SDOF systems: Single Degree-of-Freedom systems

${ }^{6}$ FEMA-440: Improvement of Nonlinear Static Seismic Procedures. Technical report, Department of Homeland Security Federal Emergency Agency, Washington D.C., USA (2005).

7 ATC 40: Recommended Methodology for Seismic Evaluation and Retrofit of Existing Concrete Buildings, Applied Technology Council, Redwood City, CA (ATC, 1996).

8 FEMA 356: Prestandard and Commentary for the Seismic Rehabilitation of Buildings (ASCE Standards Committee on Seismic Rehabilitation, 2000).
} 
element. The parameters involved in this calibration are obtained from the constitutive model described in (Penna et al., 2014) and from (Man \& Müller, 1982).

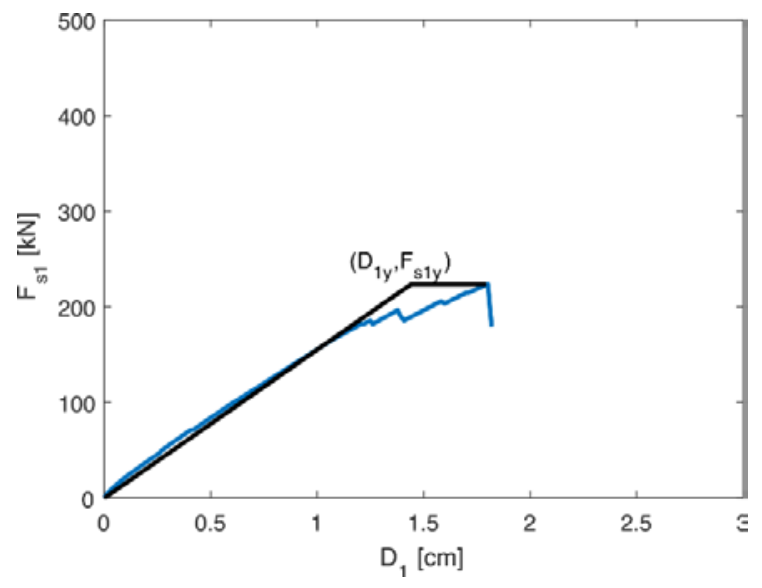

(a)

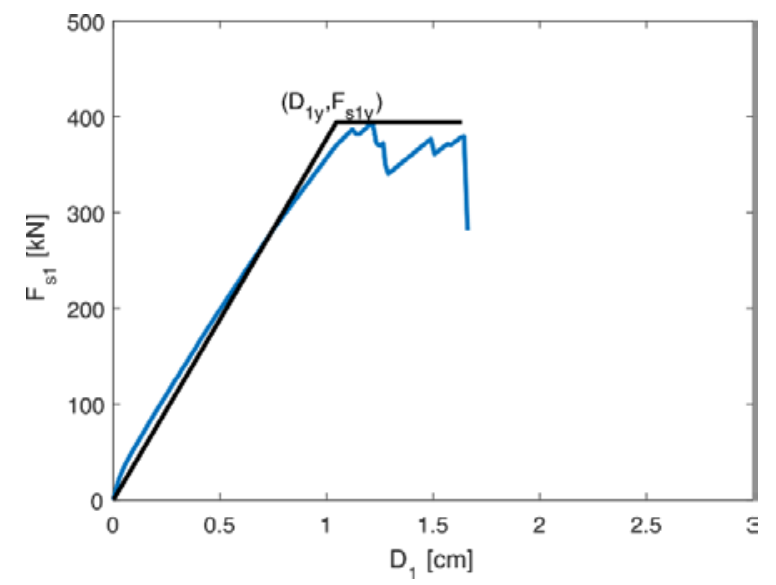

(b)

Figure 9. First mode inelastic pushover curve presenting the resisting force $F_{\mathrm{s} 1}=V_{\mathrm{b} 1} / \Gamma_{1}$ as a function of the dimensionless displacement $D_{1}=u_{\mathrm{r} 1} /\left(\Gamma_{1 ø r 1}\right)$ (blue line) and elastic-perfectly plastic approximation with yield values $D_{1 y}$ and $F_{\text {s1y }}$ (black line) for model 54 with (a) hollow and (b) solid bricks.

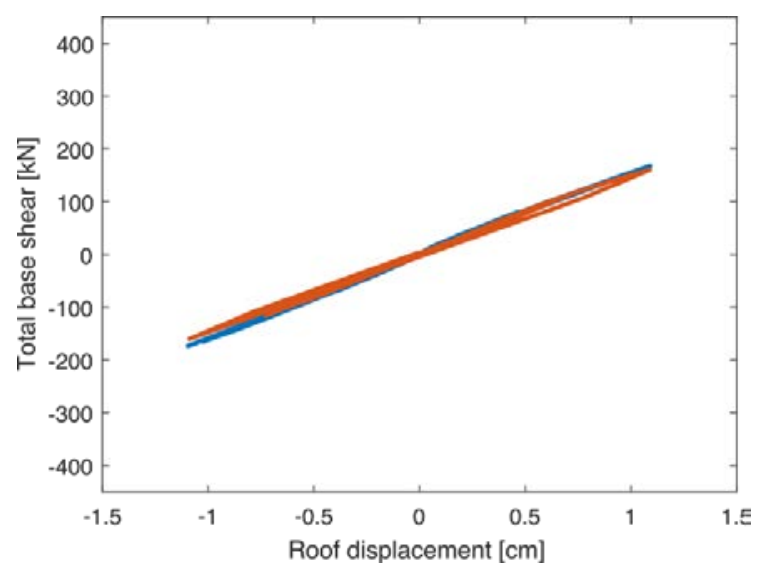

(a)

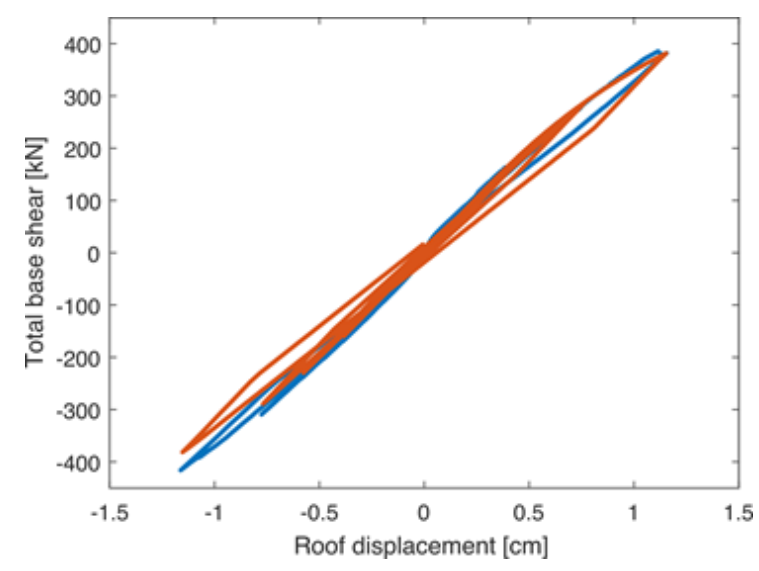

(b)

Figure 10. Pushover curves obtained from cyclic analysis of model 54 with (a) hollow and (b) solid bricks, modeled as a MDOF system using the equivalent frame method (blue line) and a single equivalent macro-element (red line).

Figure 10 presents the force-displacement curve obtained from cyclic analysis of the structure modelled as a MDOF system (model 54) using the equivalent frame method and its single equivalent macro-element, showing good agreement for target displacements below the collapse value. The cyclic response presented in Fig. 10a corresponds to a macro-element with width $b=0.89 \mathrm{~m}$, height $h=1.0 \mathrm{~m}$, and thickness $t=0.4 \mathrm{~m}$, while Fig. 10b shows the response of a macro-element with width $b=1.61 \mathrm{~m}$, height $h=1.0 \mathrm{~m}$, and thickness $t=0.5 \mathrm{~m}$. Both models show little degradation after each cycle. Fig. 10a presents less damage due to higher participation of the concrete columns, which contribute to ductility (Brzey, 2007). These models perform well for a range of displacements and drifts below the maximum recommended values, presenting damage values in agreement with reported damage in masonry buildings after an earthquake (Graziotti, Penna, Bossi \& Magenes, 2014). These results allow concluding that the single equivalent macro-element can be a correct approximation to estimate the seismic demands from different ground motions, using non-linear dynamic analysis. 


\section{VULNERABILITY ANALYSIS}

Structural vulnerability is defined as the relation between hazard and structural capacity. Ground motions are selected from the PEER Ground Motion Database (Baker, Lin, Shahi, \& Jayaram, 2011), using earthquake records compatible with the design spectrum from the Ecuadorian seismic code for the city of Cuenca for 21 PGA levels from $0.05 \mathrm{~g}$ to $0.3 \mathrm{~g}$ with an increment of $0.0125 \mathrm{~g}$, soil type C (dense soils or soft rock with a shear wave velocity between 360 and $760 \mathrm{~m} / \mathrm{s}$ ) and a damping ratio of $5 \%$. As an example, Fig. 11a shows the design spectrum for a PGA level of $0.15 \mathrm{~g}$, together with response spectra for 20 records, corresponding to earthquakes with magnitude between Mw4.0 and Mw6.0, selected from PEER Ground Motion Database (Baker et al., 2011), in such a way that their mean value is between 0.9 and 1.3 times the value of the design spectrum for periods between $0.15 \mathrm{~s}$ and $1.0 \mathrm{~s}$. Fig. 11b shows similar results for a PGA level of $0.25 \mathrm{~g}$, in which case earthquakes with magnitude between Mw5.0 and Mw7.0 have been selected form the PEER Ground Motion Database.

Non-linear dynamic time history analyses were performed using the equivalent macro-elements and the ground motions corresponding to each PGA level, which is used as the ground motion intensity measure. The maximum lateral displacement is subsequently compared with the different limit states, as defined in Fig. 7. All models are considered independent and excited by all ground motions. The ground motions are ordered according to the design spectrum previously used to identify them. The probability of exceeding a limit state is obtained by counting the exceedance that each ground motion causes to the models at a corresponding PGA level. Table 3 shows the number of exceedance at each limit state at different PGA levels for the building with masonry composed of solid bricks. The maximum number of exceedance, in any case, is 2000, obtained by multiplying the number of records per PGA level (20) with the number of models (100).

Table 3. Number of exceedance of limit states, fully operational, operational, life save and near collapse, due to ground motions selected using 21 design spectrums with PGA levels varying from $0.05 \mathrm{~g}$ to $0.3 \mathrm{~g}$ with an increment of $0.0125 \mathrm{~g}$.

\begin{tabular}{ccccc}
\hline $\begin{array}{c}\text { PGA } \\
{[\mathrm{g}]}\end{array}$ & $\begin{array}{c}\text { Fully } \\
\text { operational }\end{array}$ & Operational & $\begin{array}{c}\text { Life } \\
\text { save }\end{array}$ & $\begin{array}{c}\text { Near } \\
\text { collapse }\end{array}$ \\
\hline 0.0500 & 0 & 0 & 0 & 0 \\
0.0625 & 0 & 0 & 0 & 0 \\
0.0750 & 107 & 0 & 0 & 0 \\
0.0875 & 284 & 3 & 0 & 0 \\
0.1000 & 300 & 7 & 0 & 0 \\
0.1125 & 434 & 17 & 0 & 0 \\
0.1250 & 473 & 33 & 0 & 0 \\
0.1375 & 575 & 83 & 0 & 0 \\
0.1500 & 603 & 163 & 0 & 0 \\
0.1625 & 1218 & 242 & 0 & 0 \\
0.1750 & 1277 & 272 & 2 & 0 \\
0.1875 & 1290 & 425 & 5 & 2 \\
0.2000 & 1468 & 460 & 8 & 7 \\
0.2125 & 1489 & 466 & 13 & 10 \\
0.2250 & 1504 & 485 & 142 & 107 \\
0.2375 & 1587 & 530 & 142 & 107 \\
0.2500 & 1830 & 610 & 142 & 107 \\
0.2625 & 1830 & 685 & 143 & 108 \\
0.2750 & 1922 & 743 & 282 & 212 \\
0.2875 & 1949 & 744 & 285 & 214 \\
0.3000 & 1963 & 1375 & 435 & 327 \\
\hline
\end{tabular}

The statistical procedure for fitting the fragility functions is based on the Maximum Likelihood Estimation (MLE) method (Shinozuka, Feng, Lee \& Naganuma, 2000), which looks for the probability distribution that makes the observed data (exceedance of a limit state) most likely, and is defined by: 


$$
L=\prod_{j=1}^{m}\left(\begin{array}{l}
n_{j} \\
z_{j}
\end{array}\right) p_{j}^{z_{j}}\left(1-p_{j}\right)^{n_{j}-z_{j}}
$$

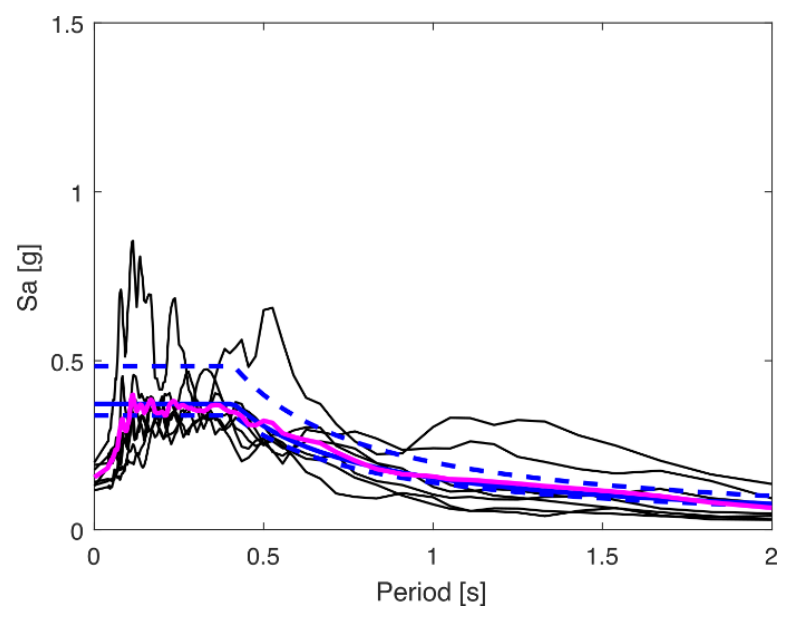

(a)

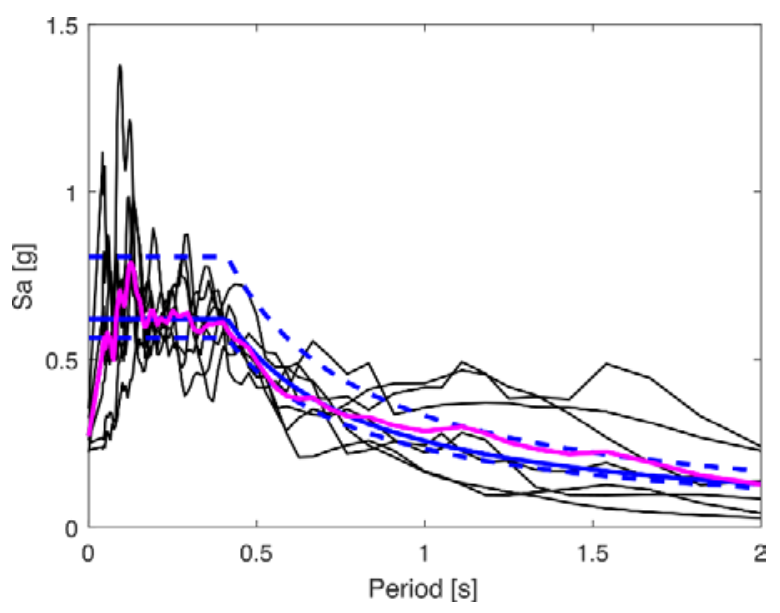

(b)

Figure 11. Design spectrum (blue solid line) from the Ecuadorian seismic code for the city of Cuenca for a PGA of (a) $0.15 \mathrm{~g}$ and (b) $0.25 \mathrm{~g}$, soil type C, and a damping ratio of $5 \%$. Superimposed on each figure are response spectra of 7 selected records (black solid lines) and their mean value (magenta solid line) that is between 0.9 and 1.3 times the value of the design spectrum (blue dashed lines) for periods between $0.15 \mathrm{~s}$ and $1.0 \mathrm{~s}$.

where $m$ represents the number of PGA levels, $n_{j}$ the number of ground motions, $z_{j}$ the number of incidents exceeding a damage state, and $p_{j}$ the probability that a ground motion $x_{j}$ results in exceedance of a limit state LS, as specified by a fragility function:

$$
p_{j}\left(L S \mid \mathrm{PGA}=x_{j}\right)=\Phi\left(\frac{\ln x_{j}-\mu}{\beta}\right)
$$

where $\Phi$ is the log-normal cumulative distribution function and $\mu$ and $\beta$ are the mean and standard deviation of $\ln x$. Estimates of the parameters $\mu$ and $\beta$ are obtained by maximizing the likelihood $L$ defined in equation (4), after insertion of the probability $p_{j}$ defined in equation (5):

$$
\{\hat{\mu}, \hat{\beta}\}=\max _{\mu, \hat{\beta}} \prod_{j=1}^{m}\left(\begin{array}{c}
n_{j} \\
z_{j}
\end{array}\right) \Phi\left(\frac{\ln x_{j}-\mu}{\beta}\right)^{z_{j}}\left(1-\Phi\left(\frac{\ln x_{j}-\mu}{\beta}\right)\right)^{n_{j}-z_{j}}
$$

This problem is solved by means of an optimization algorithm.

Figure 12 shows the fragility curve for the structure with hollow and solid bricks. For the structure with hollow bricks, the probability of collapse at a PGA of $0.25 \mathrm{~g}$ is larger than $95 \%$, while for the structure with solid bricks, the probability of collapse at the same PGA is $10 \%$. It is important to notice, however, that this preliminary study is subject to several types of uncertainty (geometry, material properties, boundary conditions, structural behavior, modeling assumptions), so further analysis and experimental testing is needed to confirm the results obtained. 


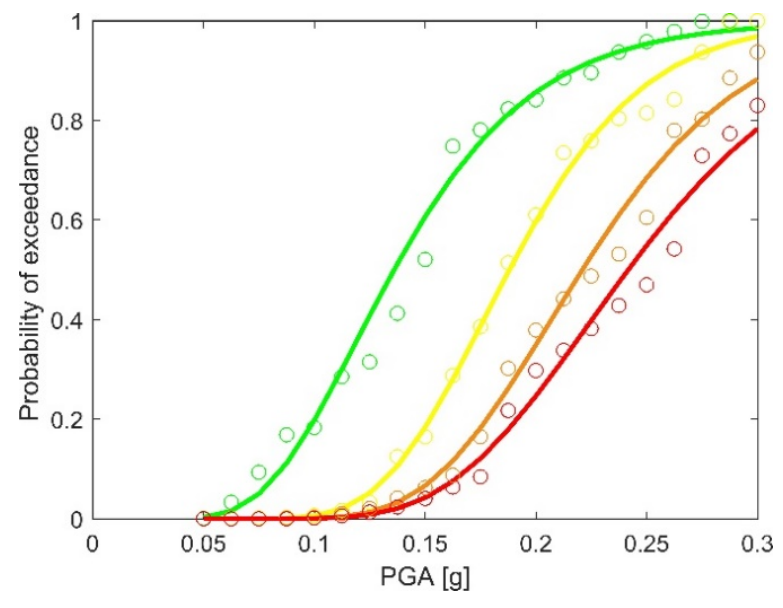

(a)

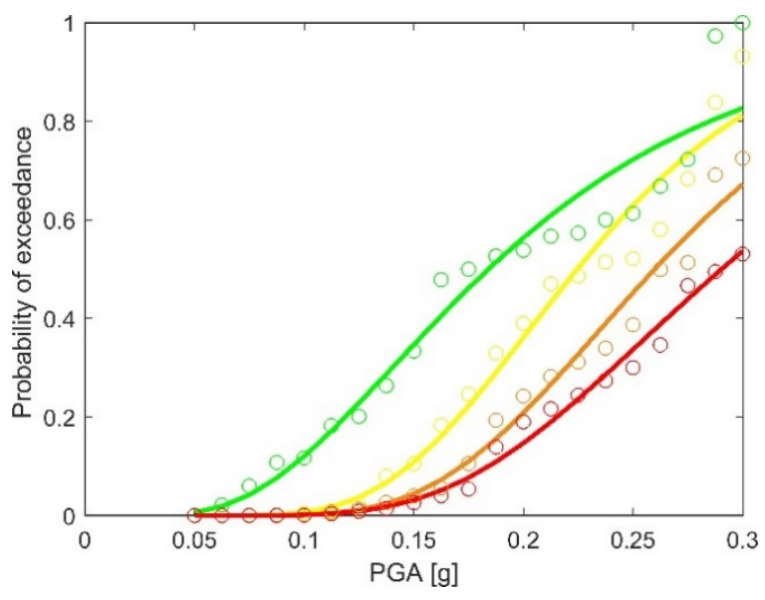

(b)

Figure 12. Fragility curves for the structure with (a) hollow and (b) solid bricks for different performance levels: fully operational (green line), operational (yellow line), life safe (orange line), and near collapse (red line).

\section{CONCLUSIONS}

A seismic vulnerability analysis is presented for the dwelling of a single family built in confined masonry, consisting of hollow or solid bricks, as typical for recent construction practice in the city of Cuenca, Ecuador. The work is motivated by the lack of research on this building topology and by previous results presenting a high level of vulnerability for this type of buildings.

The macroscopic properties of the homogenized masonry panels were derived from mesoscopic finite element analyses of masonry panels consisting of bricks and mortar layers loaded in compression and shear, respectively. Walls were modeled with an equivalent frame method implemented in TREMURI, in which piers and spandrels are characterized as macro-elements.

Non-linear static analyses on the 3D structures were performed to define the pushover curves, which were used to obtain single equivalent macro-elements capable of modeling in-plane shear and flexural failure. The maximum displacement obtained from non-linear dynamic time history analyses on the equivalent macro-elements, using earthquake records compatible with the design spectrum for the city of Cuenca for different PGA levels, were compared with limit states defined on the pushover curve. Every demand exceeding a limit state was counted and fragility curves were determined using the Maximum Likelihood Estimation method.

The results demonstrate that the level of vulnerability highly depends on material characteristics, contrary to results of a previous large scale vulnerability analysis, where all masonry buildings were treated as similar with the same probability of collapse. A high probability of collapse is shown for masonry structures with hollow bricks, subjected to ground motions with PGA ranging from $0.25 \mathrm{~g}$ to $0.30 \mathrm{~g}$. It is therefore important to control the quality of materials used as this could importantly influence structural safety in case of strong earthquakes.

The fragility curves presented in this paper are the result of a preliminary study and subject to uncertainty (geometry, boundary conditions, structural behavior, modeling assumptions). Further analysis and experiments on materials and structural components are needed before these results can be confirmed.

\section{ACKNOWLEDGEMENTS}

This work is carried out with the support of SENESCYT and the University of Cuenca. 


\section{REFERENCES}

Baker, J. W., Lin, T., Shahi, S. K., Jayaram, N. (2011). New ground motion selection procedures and selected motions for the PEER transportation research program. Peer Report 2011, 3, 86 ppAvail. Pacific Earthquake Engineering Research Center, College of Engineering, University of California, Berkeley, CA. Available at http://peer.berkeley.edu/transportation/wpcontent/uploads/2010/09/Baker_et_al_2011_PEER_GM_report.pdf

Benedetti, D., Benzoni, G., Parisi, M. (1988). Seismic vulnerability and risk evaluation for old urban nuclei. Earth-quake Engineering and Structural Dynamics, 16(2), 183-201.

Bermeo, H., Loaiza, V. (2001). Generación de escenarios de daño sísmico en la ciudad de Cuenca. Bachelor thesis en Ingeniería Civil, 177 pp. Facultad de Ingeniería, Universidad de Cuenca, Cuenca, Ecuador.

Chopra, A. K., Goel, R. K. (2002). A modal pushover analysis procedure for estimating seismic demands for buildings. Earthquake Engineering and Structural Dynamics, 31(3), 561-582.

Comité Ejecutivo de la Norma Ecuatoriana de la Construcción. (2011). Peligro sísmico y requisitos de diseño sismoresistente. Technical report, Quito, Ecuador.

European Committee for Standardization. (2004). Eurocode 8: Design provisions for earthquake resistance of structures - Part 1: General rules, seismic actions and rules for buildings. BS EN 1998-1:2004, 232 pp. Available at http://files.isec.pt/DOCUMENTOS/SERVICOS/BIBLIO/ Documentos\%20de\%20acesso\%20remoto/Eurocode-8-1-Earthquakes-general.pdf

Fajfar, P. (2000). A nonlinear analysis method for performance-based seismic design. Earthquake Spectra, 16(3), 573-592.

Freeman, S. A. (1998). The capacity spectrum method as a tool for seismic design. In: Bisch, P., Labbé, P., Pecker, A. (Eds.). Proceedings of the 11th European Conference on Earthquake Engineering, Paris, France, September.

Graziotti, F., Penna, A., Bossi, E., Magenes, G. (2014). Evaluation of displacement demand for unreinforced masonry buildings by equivalent SDOF systems. In: Cunha, A., Caetano, E., Ribeiro, P., Müller, G. (Eds.). Proceedings of the 9th International Conference on Structural Dynamics, EURODYN2014, pp. 365-372, Porto, Spain, June.

Jiménez, J. (2002). Vulnerabilidad sísmica de las edificaciones de la ciudad de Cuenca mediante técnicas de simulación. Tesis (Master en Ingeniería Estructural), 291 pp. Facultad De Ciencias, Especialista en Ingeniería Estructural Escuela Politécnica Nacional, Quito, Ecuador.

Lagomarsino, S., Galasco, A., Penna, A., Cattari, S. (2008). TREMURI: Seismic analysis program for 3D masonry buildings. User's guide. University of Genoa, Genova, Italy. Available at https://es.scribd.com/document/293817607/TREMURI-Research-Manual

Lagomarsino, S., Penna, A., Galasco, A., Cattari, S. (2013). TREMURI program: An equivalent frame model for the nonlinear seismic analysis of masonry buildings. Engineering Structures, 56, 1787-1799.

Neira, F., Ojeda, L. (1992). Dinteles de ladrillo armado. Tesis en Ingenieria Civil, 201 pp. Facultad de Ingeniería, Universidad de Cuenca, Cuenca, Ecuador.

Penna, A., Lagomarsino, S., Galasco, A. (2014). A nonlinear macroelement model for the seismic analysis of masonry buildings. Earthquake Engineering and Structural Dynamics, 43(2), 159-179.

Quito, P. (2012). La mampostería estructural como alternativa para reducir la vulnerabilidad sísmica de la vivienda de interés social. Master’s thesis, 663 pp. Facultad de Ingeniería, Universidad de Cuenca, Cuenca, Ecuador.

Shinozuka, M., Feng, M., Lee, J., Naganuma, T. (2000). Statistical analysis of fragility curves. ASCE Journal of Engineering Mechanics, 126(12), 1224-1231. 
Tomazevic, M. (1999). Earthquake-resistant design of masonry buildings. Series in Innovation in Structures and Construction ( $1^{\text {st }}$ ed.), 12 pp. London, UK: World Scientific Publishing Company. Available at http://www.worldscientific.com/doi/pdf/10.1142/9781848160835_fmatter 